\title{
Uji Kinerja Surface Scanner 3D Menggunakan Sensor VL53L0X dan Mikrokontroler ATMEGA8535
}

\author{
Putut Son Maria ${ }^{1}$ dan Elva Susianti ${ }^{2}$ \\ ${ }^{1}$ Jurusan Teknik Elektro, Fakultas Sains dan Teknologi, Universitas Islam Negeri Sultan Syarif Kasim Riau \\ ${ }^{2}$ Jurusan Teknik Elektronika, Politeknik Caltex Riau \\ putut.son@gmail.com ${ }^{1}$,elva@pcr.ac.id ${ }^{2}$
}

\begin{abstract}
Digital data recording of the geometry of 3-dimensional objects require a 3D scanner tool which are mostly using an imagery sensor. However there is hardly used information of scanned result, named color. Imagery sensor requires high spesification processing unit as capable as a personal computer for data acquisition processing. This research aims to build a $3 D$ surface scanner using a time of flight laser ranging sensor and to develop its simple function to become more valuable device. Using point to point displacement method, the sensor measures the distance between the outermost point of the object and the sensor surface perpendicularly, once when one measurement is done then the object to be rotated along with the rotary table. The prototype was built using the VL53LOX sensor and ATMEGA8535 microcontroller as a motor controller for rotary table and vertical axis. Scanned data is sent from the microcontroller to the computer to be visualized in real time. The results show that the VL5LOX sensor is suitable for scanning convex objects but it is not capable to handle objects with multiple cavities.
\end{abstract}

Keywords-Scanner 3D, VL53LOX, ATMEGA8535

\begin{abstract}
Abstrak- Perekaman data secara digital terhadap geometri dari sebuah obyek 3 dimensi memerlukan alat berupa scanner 3D. Sebagian besar scanner 3D yang telah dikembangkan umumnya didominasi menggunakan imagery sensor yang mana tidak semua entitas informasi akan diolah lebih lanjut, misalnya informasi warna. Imagery sensor memerlukan pendamping berupa laser untuk menunjang proses kerjanya selain itu juga memerlukan pengolah digital yang berspesifikasi setingkat Personal Computer. Penelitian ini bertujuan untuk membangun surface scanner 3D menggunakan sensor jarak yang mana tipikal fungsinya yang sangat sederhana akan dikembangkan utilitasnya untuk membangun sistem yang lebih bernilai signifikan. Metode yang digunakan adalah perekaman point per point dengan mekanisme rotasi obyek, yaitu sensor mengukur jarak antara titik terluar dari sisi obyek terhadap permukaan sensor secara perpendicular, setelah usai satu titik pengukuran maka kemudian obyek yang dipindai akan dirotasi bertumpu pada rotary table. Prototipe dibangun menggunakan sensor VL53L0X dan mikrokontroler ATMEGA8535 sebagai pengendali motor untuk rotary table dan vertical mover. Data hasil pemindaian dikirim oleh mikrokontroler menuju komputer untuk divisualisasikan secara real time. Hasil pengujian menunjukkan bahwa sensor VL53LOX sesuai untuk memindai obyek yang bersifat convex tetapi kurang sesuai untuk memindai obyek dengan banyak cavity.
\end{abstract}

Kata kunci-Scanner 3D, VL53L0X, ATMEGA8535

\section{Pendahuluan}

Teknologi untuk memindai obyek 3 dimensi (3D) secara non-contact telah dikembangkan sejak tahun 1980-an dengan menggunakan sumber cahaya, kamera dan proyektor [1]. Hal positif dari teknik non-contact adalah minimnya risiko kerusakan terhadap benda obyek akibat proses pemindaian. Teknik tersebut akan sangat sesuai pada berbagai karakter geometri obyek 3D yang dipindai, terutama jika obyek yang dipindai bersifat fragile atau memiliki nilai sejarah dan seni yang tinggi.

Beberapa contoh tranduser yang digunakan sebagai sensor yang telah digunakan pada beberapa penelitian diantaranya adalah Kamera Microsoft Kinect, Laser Range Finder,
OPTO-HE dan Webcam. Semua perangkat tersebut secara teknis memiliki spesifikasi yang tinggi sehingga untuk dapat memfungsikan device tersebut memerlukan pendukung berupa hardware yang memadai dan software atau pemrograman yang menggunakan library masif. Penggunaan sensor imagery berupa kamera Kinect untuk memindai obyek dummy dan membuat model rekonstruksi telah dilakukan oleh [2]. Obyek dummy dipindai dari sisi muka obyek tanpa menambahkan mekanisme untuk mengubah posisi obyek. Hasilnya menunjukkan bahwa tingkat error dari depth obyek bernilai cukup besar, penyebabnya ditengarai karena sistem melakukan hanya satu sudut pemindaian. Peneliti [3] menggunakan metode triangulation untuk memindai benda kerja dalam rangka reverse engineering. Metode tersebut 
memerlukan kamera, mikrokontroler dan laser source khusus yang berpola stripe. Hasil pemindaian telah dapat merekonstruksi bentuk replika 3D secara kasar, namun demikian pemindaian pada sisi miring dari obyek ternyata tidak dapat diterjemahkan secara akurat oleh sistem. Metode lainnya seperti pada [4], [5], [6], dan [7] masing-masing secara berurutan menggunakan sensor OPTO-HE, Raspberry $\mathrm{Pi}$ dengan jumlah puluhan, kamera khusus dan joint armed robot tidak serta merta menjamin bahwa sistem scanner yang dibangun akan optimal dan efisien.

Tipikal scanner 3D yang menggunakan imagery sensor adalah peran komputer mencakup sebagai data generator, data acquisitioner dan visual display. Fungsi komputer pada sistem tersebut adalah dominan karena untuk mengimbangi spesifikasi tinggi dari piranti sensoriknya. Pada sistem yang lebih sederhana, dapat dirancang agar sistem sensorik menggunakan non-imagery sensor sehingga peran sebagai data generator dapat ditangani oleh mikrokontroler dan komputer hanya sebagai penampil visual. Penulis menemukan hanya satu penelitian yang menggunakan non-imagery sensor untuk sistem scanner 3D yang dilakukan oleh [8]. Metode yang digunakan adalah memanfaatkan sensor jarak yang menggunakan gelombang ultrasonik dimana mikrokontroler sebagai data generator dan komputer sebagai visual display, dan hasilnya telah dapat memvisualisasikan envelope surface dari obyek yang dipindai walaupun terbatas hanya pada obyek silindris.

Penelitian ini bertujuan untuk membangun surface scanner 3D menggunakan komponen non-imagery sensor berupa VL53L0X TOF (Time of flight) laser ranging sensor yang mana masih dapat di-handle oleh mikrokontroler sebagai pengendalinya dan sekaligus sebagai data generator. Fungsi default sensor jarak yang hanya mampu memberikan satu jenis besaran akan dikembangkan utilitasnya untuk membangun sistem yang lebih bernilai signifikan. Beberapa bentuk geometri obyek 3D akan diujikan pada prototipe sistem yaitu obyek dengan karakter silindris, boxy, trapezoidal, dan free form sehingga dapat diketahui karakterisasi sensor VL53L0X untuk implementasi scanner 3D.

\section{Metodologi Penelitian}

\section{A. Blok Diagram Sistem}

Gambar 1 menunjukkan blok diagram sistem surface scanner 3D pada penelitian ini. VL53L0X adalah komponen sensor jarak yang menggunakan media sinar laser berdaya rendah yang telah terintegrasi dengan internal controller pada saat dipasarkan. Limit sensor sebagai tranduser elektromekanik untuk membatasi pergerakan vertical mover agar tidak menabrak spindle motor sekaligus sebagai lowoffset dari obyek. Mikrokontroler bertugas untuk melakukan request data jarak kepada sensor, mengatur pergerakan vertical mover dan rotary table, menampilkan informasi penting ke LCD dan mengirim data koordinat ke komputer melalui komunikasi UART.

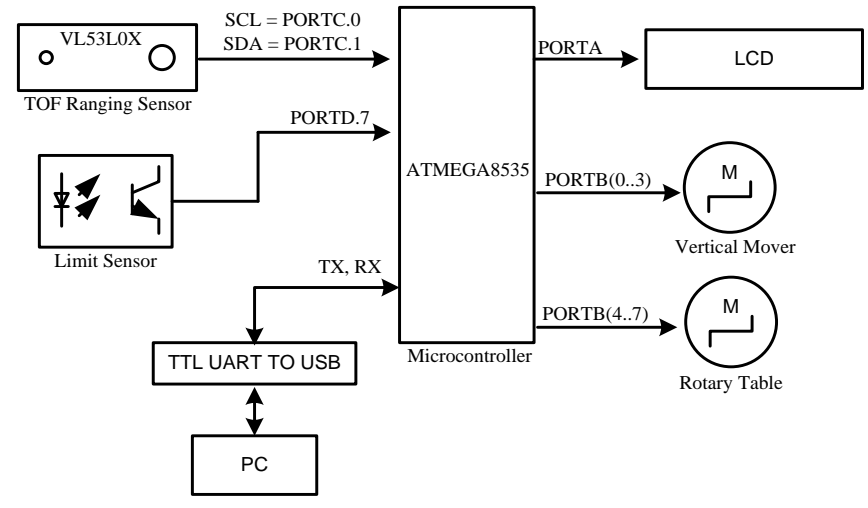

Gambar 1. Blok diagram sistem

Mekanisme pemindaian adalah dengan mengukur jarak antara sensor dengan obyek yang dipindai dan setelah itu merotasikan obyek yang dipindai sebesar sudut tertentu sesuai dengan parameter yang dipilih oleh user melalui program pengendali. Oleh karena obyek harus dirotasikan dan sensor harus bergerak vertikal sebesar jarak spasial tertentu, maka motor stepper adalah jenis penggerak yang sesuai untuk kriteria sistem di atas.

\section{B. Perumusan Koordinat 3 Dimensi}

Data yang dihasilkan dari sensor jarak adalah jarak spasial antara permukaan transmitter sensor terhadap permukaan obyek yang dipindai secara perpendicular. Untuk membuat visualisasi grafik dari obyek yang dipindai maka harus menghitung radius obyek yang sebenarnya yaitu jarak offset dikurangi dengan hasil pengukuran dari sensor seperti ditulis pada persamaan (1). Jarak offset adalah jarak antara permukaan sensor terhadap titik pusat obyek yang dipindai, dalam hal ini diukur langsung pada fisik konstruksi mekanik. Pada penelitian ini jarak offset antara permukaan transmitter sensor dengan sumbu rotary table adalah $112 \mathrm{~mm}$ seperti ditunjukkan pada Gambar 2.a.

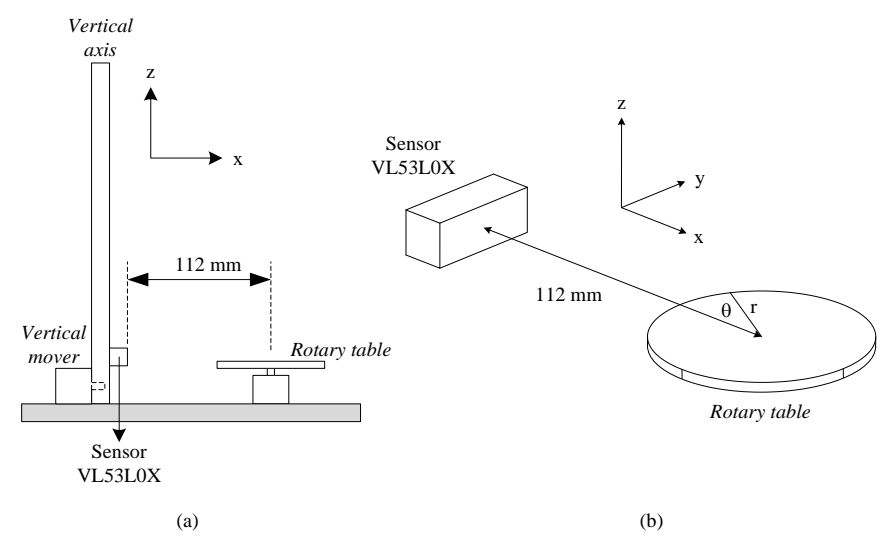

Gambar 2. Ilustrasi sistem surface scanner 3D

(a) ZX plane view

(b) 3D perspective view 
Sumbu rotasi dari rotary table sekaligus merepresentasikan titik origin atau origin point dimana nantinya visualisasi secara grafis dari obyek yang dipindai akan mengacu pada titik tersebut. Gambar 2.b menunjukkan arah vektor dari sistem koordinat 3D yang digunakan pada penelitian ini. Ilustrasi yang ditampilkan hanya fokus pada bagian sensor dan rotary table karena pada bagian ini penting untuk penurunan rumus koordinat $\mathrm{x}$ dan $\mathrm{y}$. Proyeksi radius $r$ dengan sudut $\theta$ terhadap sumbu $\mathrm{x}$ dan $\mathrm{y}$ dihitung menurut persamaan (2) dan (3).

$$
\begin{gathered}
r=112-\text { distance } \\
x=r \cos \theta \\
y=r \sin \theta
\end{gathered}
$$

\section{Skema Rangkaian dan Set Up Eksperimen}

Gambar 3 menunjukkan skema rangkaian yang digunakan pada penelitian ini. Komunikasi antara sensor VL53L0X terhadap mikrokontroler ATMEGA8535 menggunakan protokol I2C standar melalui jalur SDA (PC1) dan SCL (PC0).
Untuk men-drive motor stepper vertical mover dan rotary table digunakan PORTB. Jenis dan spesifikasi kedua motor stepper yang digunakan adalah unipolar (5 wire), 1,8\%step, 12 Volt. Komunikasi serial UART dari mikrokontroler ke Komputer menggunakan TTL to USB dongle. Setting baud rate (bps) ditetapkan sebesar 9600 bps, 8 bit, dan no parity.

Gambar 4 menunjukkan set up eksperimen pada penelitian ini. Dummy object diberikan perekat pada bagian alasnya dan diletakkan pada rotary table agar tidak mengalami pergeseran akibat hentakan motor stepper. Untuk dummy object silindris, boxy, dan trapezoidal dibuat dari bahan kertas papercraft jenis WF paper, sedangkan untuk obyek freeform adalah boneka jadi yang terbuat dari bahan plastik.

Setiap titik yang telah selesai diukur maka datanya langsung dikirim ke komputer dengan format koordinat $\mathrm{x}, \mathrm{y}$, dan $\mathrm{z}$, selanjutnya komputer akan mem-visual-kan grafik obyek secara 3D sehingga user dapat langsung mengamati proses pemindaian secara realtime.

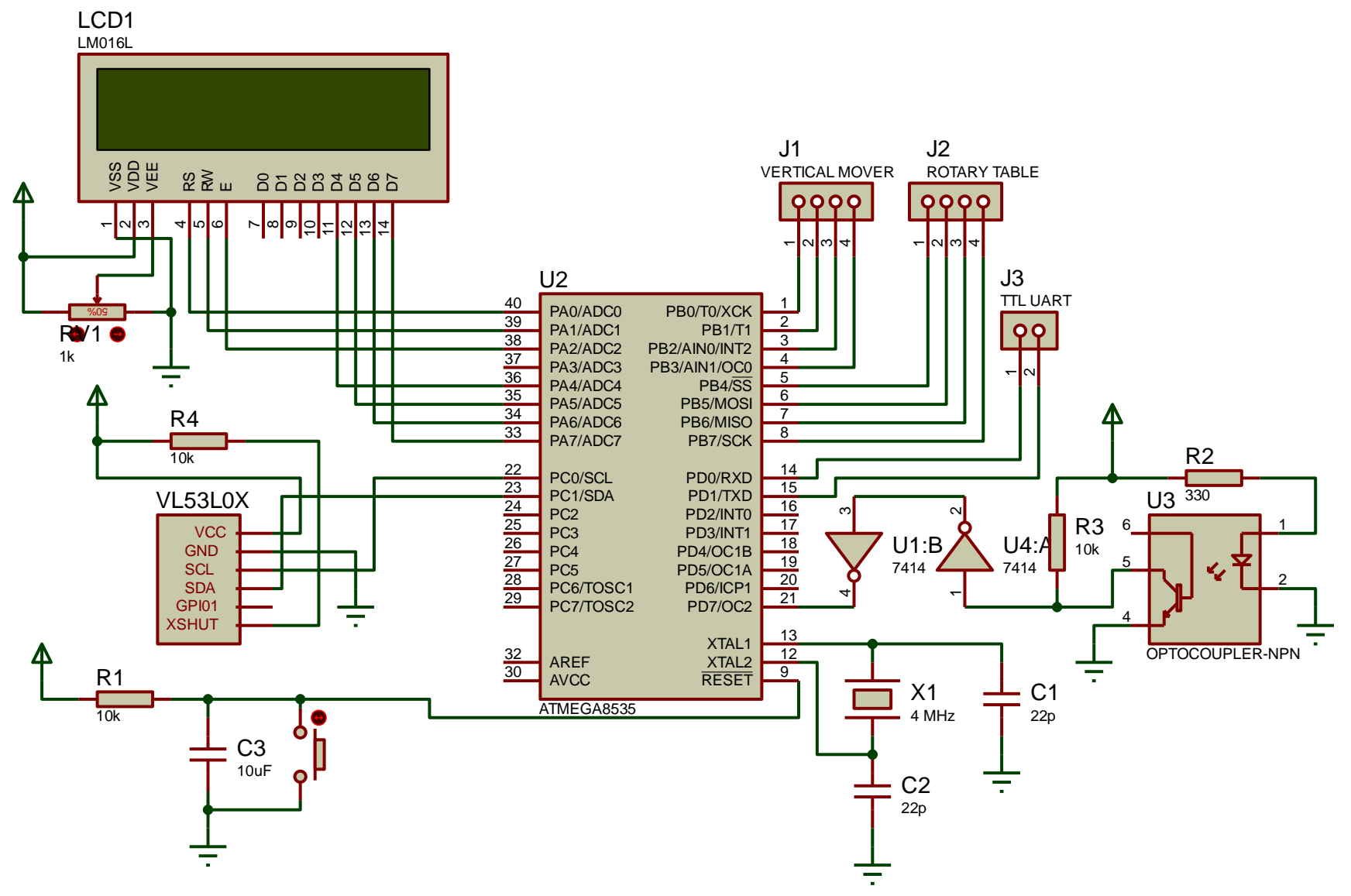

Gambar 3. Rangkaian elektronik Surface Scanner 3D pada penelitian ini 


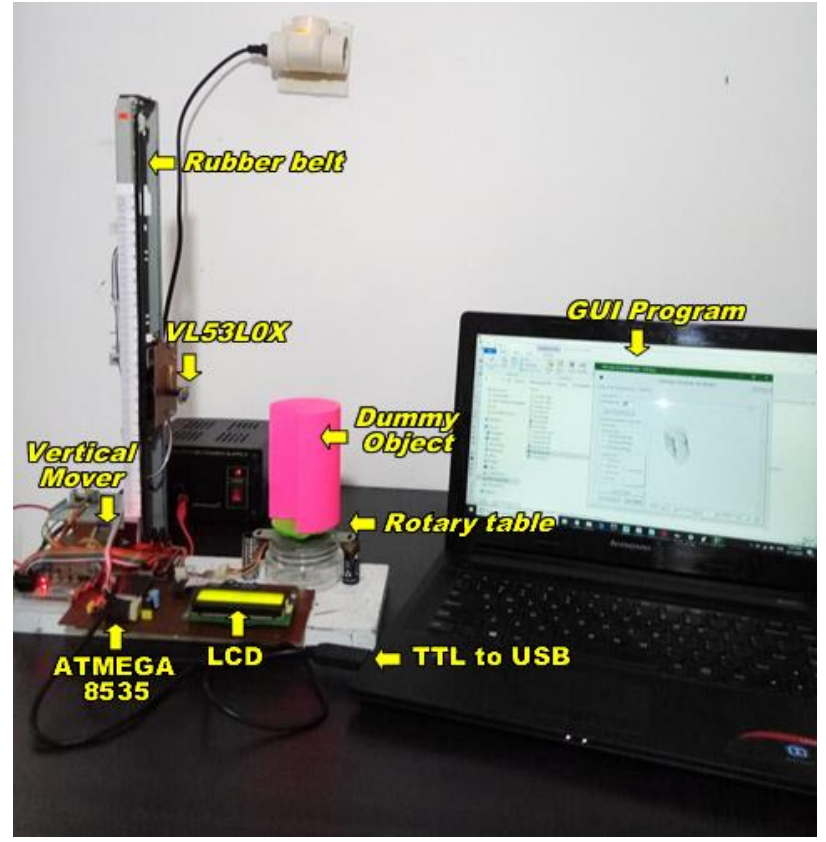

Gambar 4. Capture prototipe alat

\section{HASIL DAN PEMBAHASAN}

\section{A. Program Surface Scaner 3D}

Program pengendali bagi user yang dijalankan pada komputer dibangun menggunakan bahasa Pascal dengan compiler Delphi, pada antarmuka disediakan fitur pemilihan resolusi untuk sudut rotary table dan pergerakan vertical mover yang mana term resolusi dalam konteks ini merepresentasikan sampling rate secara spasial. Fitur tersebut untuk memfasilitasi pemindaian obyek yang memiliki banyak lekukan pada body-nya seperti pada obyek organis atau freeform. Visualisasi obyek pada program dapat dipilih sesuai perspective yang diinginkan oleh user dengan cara mengatur besaran sudut rotasi dan elevasi seperti ditunjukkan pada Gambar 5.

Meskipun jenis motor stepper yang digunakan memiliki spesifikasi sama 1,8\%step, namun demikian pilihan untuk step rotasi berbeda dengan vertikal karena tergantung pada struktur fisik sub mekanik dari prototipe.

Pada mekanik rotary table, bantalan tumpuan dummy object langsung terhubung dengan shaft dari motor stepper, sehingga azimuth terkecil dari dummy object sama dengan $1,8^{\circ}$ per step, dengan demikian untuk satu putaran penuh shaft motor dapat dihasilkan sampel data maksimum sebanyak 200 data atau ekivalen 200 data per $360^{\circ}$ rotasi. Pada program juga disediakan pilihan 100 data dan 50 data per 360 derajat yang berarti interval gerakan rotasi obyek akan terpaut sebesar $3,6^{\circ}$ dan $7,2^{\circ}$.

Bracket tempat sensor VL53L0X dipasang tertaut pada rubber belt yang akan memanifestasikan gerakan rotasi pulley pada shaft motor stepper menjadi displacement linier. Jarak perpindahan linier dipengaruhi oleh diameter pulley dan jumlah step motor, karena diameter pulley adalah tetap maka pengendalian perpindahan linier cukup dengan memberikan sejumlah step tertentu pada motor. Untuk memudahkan user dalam menentukan resolusi spasial linier maka pilihan resolusi pergerakan vertikal dinyatakan dalam besaran displacement linier yaitu $0,25 \mathrm{~cm}, 0,5 \mathrm{~cm}, 0,75 \mathrm{~cm}$, dan $1 \mathrm{~cm}$. Dengan kondisi tersebut, maka jumlah sampel data dari sebuah obyek yang dipindai ekivalen dengan perkalian antara rotational step dan tinggi obyek yang dibagi dengan vertical step.

Obyek uji yang digunakan selama eksperimen terdiri dari obyek silindris, boxy, trapezoidal, dan freeform. Dimensi masing-masing obyek ditunjukkan seperti pada Gambar 6 . Tiga model dummy object terbuat dari bahan kertas sehingga tingkat ketepatan ukurannya terdapat selisih sebesar $0,5 \mathrm{~mm}$ sampai $1 \mathrm{~mm}$ akibat proses pengeleman dan pengguntingan yang mana masih dianggap wajar.

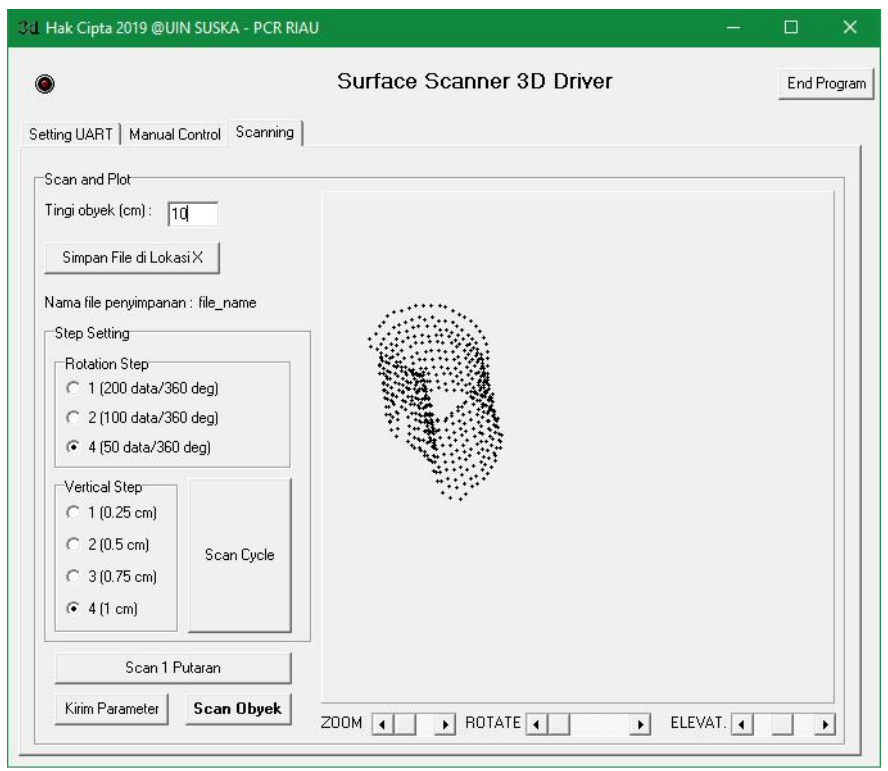

Gambar 5. Antarmuka program pengendali surface scanner 3D

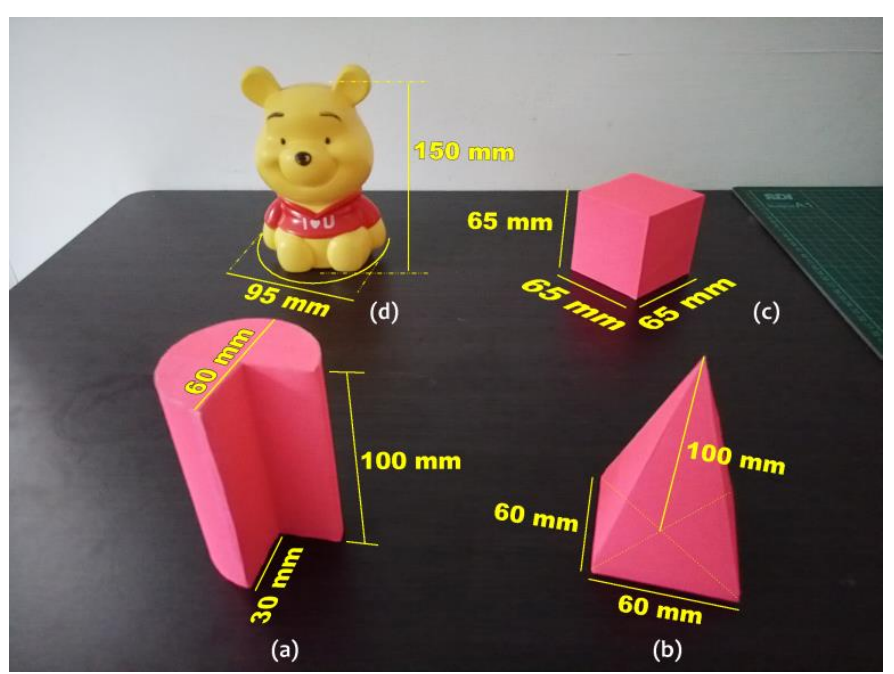

Gambar 6. Obyek uji

(a) Silindris, (b) Trapezoidal, (c) Boxy, dan (d) Freeform 


\section{B. Hasil Pemindaian Obyek Geometris}

Tabel I menunjukkan hasil pemindaian terhadap dummy object silindris dengan pengaturan resolusi pemindaian vertikal $10 \mathrm{~mm}$ dan 50 sampel data per 360 derajat rotasi obyek. Sebagai pembanding visual digunakan program AutoCAD untuk memudahkan dalam pengukuran dimensi model digital. Model yang diplot pada AutoCAD merupakan representasi dari hasil pemindaian oleh sensor yang disimpan dalam bentuk file dengan struktur koordinat x, y, dan z. Hasil plot menunjukkan bahwa sensor mampu memindai obyek silindris secara baik dengan bias pengukuran absolut sebesar $\pm 3 \mathrm{~mm}$. Nilai ini diukur dengan cara membuat lingkaran bantu dari sudut pandang top view dimana lingkaran luar, tengah dan dalam merepresentasikan radius obyek terbesar, rata-rata dan terkecil. Nilai radius rata-rata terukur sebesar $29,9 \mathrm{~mm}$ dimana nilai tersebut hampir sama dengan radius obyek aslinya sebesar $30 \mathrm{~mm}$.

Tabel II menunjukkan hasil pemindaian terhadap dummy object silindris, boxy, dan trapezoidal dengan pengaturan resolusi pemindaian vertikal $5 \mathrm{~mm}$ dan 50 sampel data per 360 derajat rotasi obyek.

Hasil pemindaian terhadap obyek silindris baik pada Tabel I atau Tabel II, prototipe telah dapat mengukur tinggi obyek secara baik, namun tingkat ketelitian sudut bagian dalam juring tidak tepat membentuk 90 derajat. Pengukuran sudut bagian dalam juring pada model rekonstruksi AutoCAD memberikan angka 101 derajat. Kesalahan hasil pemindaian tersebut dipengaruhi oleh dua faktor yaitu resolusi spasial sudut rotary table dan karakteristik berkas sinar laser dari sensor. Resolusi spasial sudut rotary table pada kedua data tersebut adalah 50 sampel/360 derajat atau ekivalen dengan 7,2 derajat/move. Hal ini berarti ada titik-titik yang terlompati dari pemindaian oleh sensor. Dengan menghitung radius silinder $30 \mathrm{~mm}$ dan sudut setiap rotasi 7,2 derajat maka setiap titik pada sisi terluar silinder akan mengalami pergeseran posisi sebesar $3,8 \mathrm{~mm} /$ move, konsekuensinya adalah titik-titik di antara setiap interval $3,8 \mathrm{~mm}$ pada sisi terluar silinder akan terlewati pemindaiannya oleh sensor. Faktor karakter berkas sinar laser dari sensor juga menyumbang kesalahan terhadap hasil pemindaian obyek. Dari [9] diketahui bahwa field of view (FOV) dari sensor adalah 25 derajat. Nilai ini relatif cukup besar jika dibandingkan dengan resolusi spasial sudut rotary table pada data. Karakteristik FOV dengan sudut 25 derajat berarti bahwa sensor akan mengukur entitas mana saja yang berjarak paling dekat dengan sensor selama entitas tersebut dalam cakupan FOV, konsekuensinya adalah titiktitik yang lebih luar akan terbaca sebagai manifestasi dari titik-titik yang lebih dekat dengan pusat rotasi obyek.

Premis di atas terbukti pada hasil pemindaian dummy object trapezoidal dan boxy. Obyek dengan puncak meruncing kurang dapat dipindai secara teliti oleh sensor. Semakin kecil sisi miring dari obyek, maka sensor menterjemahkannya sebagai bentuk melingkar. Sebaliknya jika sisi obyek berupa bidang datar dan lebar seperti pada dummy object kubus maka sensor dapat memindainya secara lebih baik.

\section{Hasil Pemindaian Obyek Freeform}

Tabel III menunjukkan hasil pemindaian terhadap dummy object freeform yang berupa boneka. Seperti pada pembahasan sebelumnya bahwa karakter sensor dengan FOV lebar akan sulit memindai titik-titik pada daerah cerukan atau cavity namun sebaliknya akan mudah memindai titik-titik pada bidang menonjol atau convex. Obyek boneka memiliki karakter kombinasi titik-titik pada daerah cavity dan convex, sehingga sesuai untuk menguji kinerja sensor pada obyek universal. Hasil pemindaian menunjukkan bahwa sensor dapat menterjemahkan secara baik pada bagian dahi, hidung dan pipi karena ketiga bagian tersebut bersifat cembung atau terekspose. Sedangkan pada bagian leher dan tangan kurang dapat diterjemahkan secara baik oleh sensor. Demikian juga pada bagian telinga boneka, sensor gagal untuk menterjemahkan pengukuran karena efek FOV dari sensor, gejala tersebut sama seperti hasil yang didapat pada pemindaian terhadap obyek trapezoidal.

TABEL I. HASIL PEMINDAIAN OBYEK SILINDRIS, RESOLUSI VERTIKAL $=10 \mathrm{MM}$, SAMPEL $/$ RoTASI $=50 / 360^{\circ}$

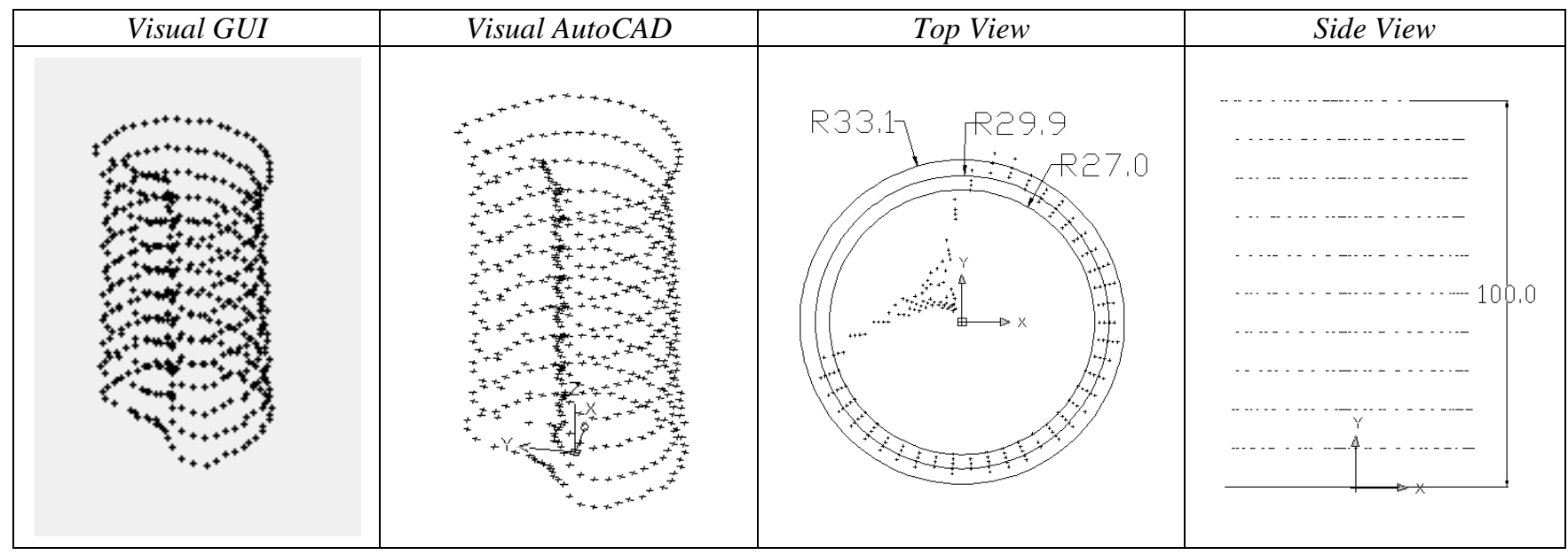


TABEL II. HASIL PEMINDAIAN OBYEK GEOMETRIS, RESOLUSI VERTIKAL $=5 \mathrm{MM}$, SAMPEL $/$ RotASI $=50 / 360^{\circ}$

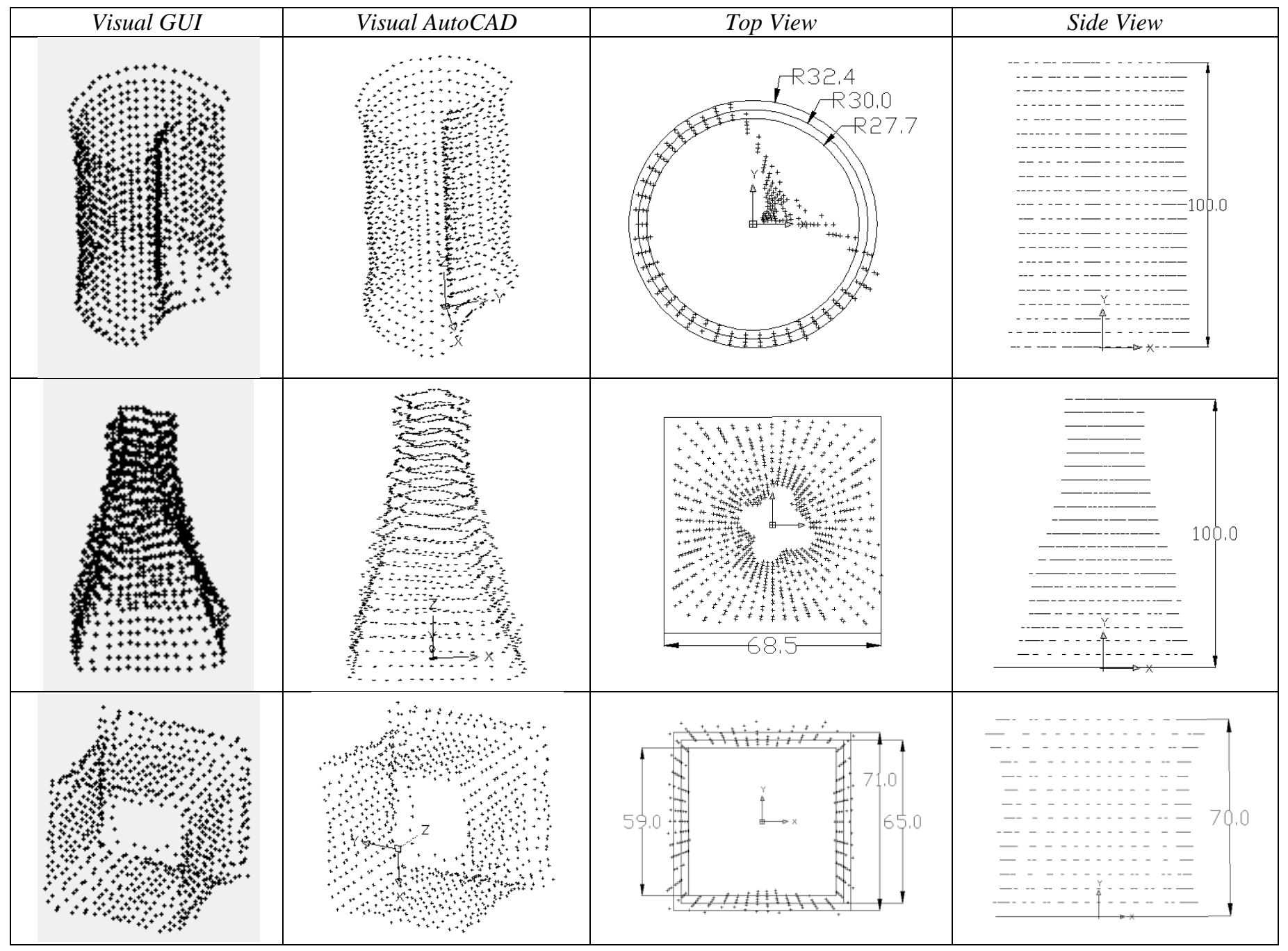

TABEL III. HASIL PEMINDAIAN OBYEK FREEFORM, RESOLUSI VERTIKAL $=5 \mathrm{MM}$, SAMPEL $/$ RoTASI $=100 / 360^{\circ}$

\begin{tabular}{|c|c|c|c|}
\hline Visual GUI & Visual AutoCAD & Top View & Side View \\
\hline & & & \\
\hline & & & \\
\hline
\end{tabular}




\section{Pembahasan}

Tabel IV menunjukkan perbandingan hasil penelitian ini dengan beberapa peneliti lain. Pada dasarnya semua peneliti yang tercantum pada Tabel IV menggunakan komputer atau personal computer (PC) untuk menampilkan hasil pemindaian. Tabel IV dapat dipilah menjadi 2 keunikan berdasarkan jenis sensor yang digunakan yaitu imagery sensor dan non-imagery sensor. Pada penelitian yang menggunakan kamera baik dalam bentuk webcam atau terintegrasi, maka semua tugas ditangani oleh komputer. Komputer berperan aktif mengakses sensor, mengolah data, mengatur pergerakan motor, dan menampilkan hasil pemindaian. Peran mikrokontroler hanya sebagai pendukung untuk meneruskan sinyal kontrol ke aktuator. Penggunaan kamera seharusnya mampu memberikan hasil yang lebih natural, namun demikian informasi sekunder seperti misalnya warna obyek yang dipindai ternyata tidak diakomodir sebagai bagian dari hasil pemindaian [2], [3], [10]. Hal ini menunjukkan bahwa parameter yang esensial dan prioritas pada pemindaian obyek 3D adalah entitas titik-titik yang tersusun membentuk model geometri menyerupai obyek aslinya.

Sebaliknya pada penelitian yang menggunakan nonimagery sensor, kemampuan untuk menghasilkan data dengan fitur beragam sangat terbatas. Fungsi dasar sensor pada sistem yang digunakan pada penelitian [8] sebanding dengan sensor pada penelitian ini yaitu hanya mampu menghasilkan data distance. Parameter akurasi pada penelitian ini belum dapat dihitung secara relatif karena untuk menghitung volume model secara akurat sangat dipengaruhi oleh proses meshing, filtering dan refining pada saat akan membentuk model dari point cloud menjadi closed surface. Namun demikian dari data hasil eksperimen menunjukkan bahwa kinerja sensor VL53L0X dalam mengukur jarak obyek memiliki toleransi nilai sebesar $\pm 3 \mathrm{~mm}$ absolute terhadap nilai real.
Waktu akuisisi data sensor pada penelitian ini masih kurang optimal karena menggunakan mode single reading. Untuk satu titik pengukuran ternyata memerlukan waktu 1,14 sampai 1,17 detik yang mana durasi ini terlalu lama. Hal ini karena default kernel protokol untuk mengakses data dari sensor VL53L0X sangat banyak jumlah perintahnya sehingga berimbas pada semakin banyaknya kode program yang harus ditulis dan pada akhirnya menggunakan sebagian besar memori program pada mikrokontroler. Kinerja yang berhubungan dengan waktu akuisisi dapat diperbaiki dengan menggunakan mode continuous reading dengan konsekuensi bahwa akan membutuhkan 2 unit mikrokontroler untuk mencapai hasil yang lebih optimal.

\section{SIMPULAN}

Prototipe surface scanner 3D menggunakan sensor VL53L0X dan mikrokontroler ATMEGA8535 telah berhasil dibuat dan bekerja secara baik. Kinerja dari prototipe tergantung pada karakteristik sensor VL53L0X dan konstruksi mekanik yang digunakan. Hasil eksperimen menunjukkan bahwa sensor VL53L0X sesuai untuk memindai obyek dengan karakteristik convex tetapi kurang sesuai untuk memindai obyek dengan banyak cavity. Ketelitian dari hasil pemindaian menggunakan teknik rotasi obyek dapat ditingkatkan dengan cara memperkecil displacement spasial baik untuk parameter translasi sensor dan rotasi obyek dengan konsekuensi bahwa jumlah vertex dalam point cloud yang dihasilkan akan semakin banyak. Scantime yang kurang optimal akan menambah lama total waktu pemindaian sebuah obyek. Scantime pada penelitian ini masih dapat diperbaiki dengan menggunakan mode continuous reading namun harus menggunakan 2 unit mikrokontroler agar kinerja prototipe lebih signifikan.

TABEL IV. PERBANDingan KinERJA SiSTEM SCANNER 3D

\begin{tabular}{|c|c|c|c|c|c|c|c|}
\hline Peneliti & Unit Pengolah & Sensor & Akurasi & $\begin{array}{c}\text { Geometri } \\
\text { Obyek }\end{array}$ & $\begin{array}{c}\text { Sampel } \\
\text { Data }\end{array}$ & $\begin{array}{c}\text { Waktu } \\
\text { Akuisisi }\end{array}$ & Warna \\
\hline $\begin{array}{c}\text { Retno Tri Wahyuni, } \\
\text { et al }[2]\end{array}$ & $\mathrm{PC}$ & $\begin{array}{l}\text { Microsoft } \\
\text { Kinect }\end{array}$ & N/A & $\begin{array}{l}\text { Letters } \\
\text { I, T, S }\end{array}$ & 3 & $N / A$ & No \\
\hline $\begin{array}{l}\text { Bolo Dwiartomo, et } \\
\text { al [3] }\end{array}$ & $\mathrm{PC}$ & $\begin{array}{l}\text { Webcam+ } \\
\text { LaserPointer }\end{array}$ & $\begin{array}{c} \pm 2,417 \\
\mathrm{~mm} \\
\text { absolute }\end{array}$ & Mechanical & 1 & N/A & No \\
\hline Edy Junaidi, et al [8] & Arduino UNO & $\begin{array}{l}\text { Ultrasonic, } \\
\text { HC-SR04 }\end{array}$ & $\begin{array}{l}59,54 \% \\
\sim 96,5 \%\end{array}$ & Silindris & 5 & $N / A$ & No \\
\hline $\begin{array}{l}\text { Arif Armansyah, et } \\
\text { al [10] }\end{array}$ & $\mathrm{PC}$ & $\begin{array}{l}\text { Microsoft } \\
\text { Kinect }\end{array}$ & N/A & $\begin{array}{l}\text { Silindris, } \\
\text { Boxy } \\
\text { Trapezoidal, } \\
\text { Freeform }\end{array}$ & 5 & $N / A$ & No \\
\hline Penelitian ini & ATMEGA8535 & $\begin{array}{l}\text { Laser Ranging, } \\
\text { VL53L0X }\end{array}$ & $\begin{array}{c} \pm 2,7 \sim 3 \\
\mathrm{~mm} \\
\text { absolute }\end{array}$ & $\begin{array}{c}\text { Silindris, } \\
\text { Boxy } \\
\text { Trapezoidal, } \\
\text { Freeform }\end{array}$ & 4 & $\begin{array}{c}1,14 \sim \\
1,17 \\
\text { sec/point }\end{array}$ & No \\
\hline
\end{tabular}




\section{REFERENSI}

[1] M. A. B. Ebrahim, "3D Laser Scanners Techniques Overview", International Journal of Science and Research, vol. 4, no. 10, pp.323331, October 2015.

[2] R. T. Wahyuni, D. Purwanto, and T. A. Sardjono, "Aplikasi Rekonstruksi 3 Dimensi pada Proses Pemahatan Menggunakan CNC", Jurnal Teknik Elektro dan Komputer, vol. 1, no. 2, pp. 180-190, October 2013.

[3] B. Dwiartomo, A. Ruswandi, and K. Nuryanto, "Implementasi Surface 3D Scanner Menggunakan Metode Triangulation dan Tesselation Untuk Reverse Engineering Obyek Sederhana”, Prosiding Seminar Nasional Teknologi Manufaktur, 2014, pp. 78 - 95.

[4] A. Kus, "Implementation of 3D Optical Scanning Technology for Automotive Applications", Sensors, vol. 9, no. 3, pp. 1967-1979, doi:10.3390/s90301967, 2009.

[5] J. Straub and S. Kerlin, "Development of a Large, Low-Cost, Instant 3D Scanner", Technologies, vol. 2, no. 2, pp. 76-95, doi:10.3390/technologies2020076, 2014.

[6] R. Usementiaga, J. Molleda, D. F. Garcia, "Structured Light Sensor Using Two Laser Stripes for 3D Reconstruction without Vibrations", Sensors, vol. 14, no. 11, pp. 20041-20063, doi:10.3390/s141120041, 2014.

[7] A. Chromy, "Application of High Resolution 3D Scanning in Medical Volumetry", International Journal of Electronics and Telecommunications, vol. 62, no. 1, pp. 23-31, doi:10.1515/eletel2016-0003, 2016.

[8] E. Junaidi, Waslaluddin, and L. Hasanah, "Rancang Bangun Scanner 3D Menggunakan Sensor Ultrasonik dengan Tampilan Realtime Berbasis Mikrokontroler", Jurnal Online Fisika(Fibusi), vol. 3, no. 2, September 2015.

[9] Datasheet VL53L0X, DocID029104 Rev 2, (2018). [Online]. Available: https://www.st.com/en/imaging-and-photonics-solutions/vl5310x.html

[10] A. Armasyah, S. Hidayatullah, and A. Herliana, "Perancangan dan Pembuatan Alat Scanner 3D Menggunakan Sensor Kinect Xbox 360”, Jurnal Informatika, vol. 5, no. 1, pp. 128-136, April 2018. 